\title{
PARTISIPASI PETANI ANGGOTA P3A PADA PENGEMBANGAN JARINGAN IRIGASI DI DAERAH IRIGASI TACCIPI
}

\author{
Participation Of P3A Member Farmers In Irrigation Network Development \\ Activities In Taccipi Irrigation Area
}

\author{
Hastika*, A. N. Tenriawaru, A. Amrullah \\ Program Studi Agribisnis, Departemen Sosial Ekonomi Pertanian, \\ Fakultas Pertanian, Universitas Hasanuddin, Makassar. \\ *Kontak Penulis: hastikatika13@gmail.com
}

\begin{abstract}
ABSTRAK
Kegiatan pertanian tidak terlepas dari air sehingga air irigasi sebagai salah satu komponen pendukung keberhasilan pembangunan pertanian. Penelitian ini bertujuan untuk: 1) Mendeskripsikan kegiatan PJI, 2) Menganalisis tingkat dan bentuk partisipasi petani anggota P3A pada kegiatan PJI. Lokasi penelitian ditentukan dengan sengaja (purposive) yaitu di Desa Malimpung, Kecamatan Patampanua Daerah Irigasi Taccipi dengan jumlah sampel sebanyak 71 petani anggota P3A yang terbagi dalam tiga kelompok P3A Jembatan Bessi (Hulu), Kaluppang (Tengah), dan Lamacinna (Hilir). Penelitian ini menggunakan metode survey (kuantitatif). Hasil penelitian menyatakan bahwa 1) Pelaksanaan kegiatan PJI di daerah irigasi Taccipi secara umum telah sesuai dengan prosedur pelaksanaan yang berlaku. Diawali dengan tahapan persiapan oleh pengurus dan anggota lainnya didampingi oleh penyuluh meliputi musyawarah anggota, survei lokasi dan pengukuran, serta pembuatan proposal. Kemudian pelaksanaan konstruksi dilakukan secara swakelola dengan memanfaatkan tenaga kerja anggotanya meliputi pembersihan lokasi, pembelian bahan material, persiapan alat dan tenaga kerja serta pelaksanaan konstruksi itu sendiri, 2) Tingkat Partisipasi petani anggota P3A Jembatan Bessi (hulu), P3A Kaluppang (tengah), dan P3A Lamacinna (hilir) pada kegiatan penyusunan rencana usulan kelompok dan kegiatan konstruksi (pembangunan baru) saluran tersier relatif sama berada pada kategori rendah. Bentuk partisipasi petani anggota P3A mulai dari partisipasi bentuk pemikiran berupa ide, saran/pendapat, bentuk tenaga kerja berupa ikut membantu membersihkan lokasi jaringan irigasi, bentuk bahan banguan berupa jasa penyedia pengambilan bahan bangunan, bentuk dana sudah tersedia dalam mata anggaran belanja bantuan sosial, dan bentuk pemeliharan hanya dilakukan oleh para pekerja/tenaga kerja masing-masing kelompok P3A.
\end{abstract}

Kata Kunci: partisipasi; anggota P3A; pengembangan jaringan irigasi; irigasi.

\section{ABSTRACT}

Agricultural activities cannot be separated from water so that irrigation water is one of the supporting components of the success of agricultural development. This study aims to: 1) Describe PJI activities, 2) Analyze the level and form of participation of P3A member farmers in PJI activities. The research location was determined intentionally, namely in Malimpung Village, Patampanua District, Taccipi Irrigation Area with a sample of 71 P3A member farmers divided into three groups P3A Jembatan Bessi (Upstream), Kaluppang (Center), and Lamacinna (Downstream). This research uses survey methods (quantitative). The results of the study state that 1) Implementation of PJI activities in the Taccipi irrigation area in general is in accordance with the applicable implementation procedures. It starts with the preparation stage by the management and other members accompanied by extension agents including member meetings, location surveys and measurements, and making proposals. Then the implementation of the development is carried out in a self-managed manner by 
utilizing the workforce of its members including site cleaning, material purchase, preparation of equipment and labor and construction itself, 2) Participation Level of farmers members of P3A Jembatan Bessi (upstream), P3A Kaluppang (center), and P3A Lamacinna (downstream) in the formulation of proposed group activities and construction activities (new development) tertiary channels are relatively the same in the low category. The form of farmers' participation in the P3A starts from the participation of thought forms in the form of ideas, suggestions / opinions, forms of manpower helping to clean the location of irrigation networks, building materials in the form of collection services, forms of funds already available on social assistance budgets, and maintenance by workers / laborers from each P3A group.

Keywords: Participation; P3A member; Irrigation Network Development (PJI); Irrigation.

Sitasi: Hastika*, A. N. Tenriawaru, A. Amrullah, 2019. Partisipasi Petani Anggota P3A Pada Kegiatan Pengembangan Jaringan Irigasi (PJI) Di Daerah Irigasi Taccipi, JSEP 15(2): $124-134$.

\section{Pendahuluan}

Kegiatan pertanian tidak terlepas dari air. Oleh sebab itu, irigasi sebagai salah satu komponen pendukung keberhasilan pembangunan pertanian mempunyai peran sangat penting. Keterbatasan anggaran yang dimiliki pemerintah mengakibatkan dana operasi dan pemeliharaan terbatas sehingga banyak kondisi teknis jaringan irigasi yang secara fisik dan fungsi terganggu. Hal ini dapat diatasi melalui kerja sama antara pemerintah dan masyarakat khususnya petani (Lugiarti, 2004). Sesuai dengan PP 20/ 2006 tentang irigasi mengenai partisipasi masyarakat petani menyebutkan bahwa: "Partisipasi masyarakat petani dalam pengembangan dan pengelolaan sistem irigasi diwujudkan mulai pemikiran awal, pengambilan keputusan, dan pelaksanaan kegiatan dalam pembangunan, peningkatan, operasi, pemeliharaan, dan rehabilitasi".

Mengingat kompleksnya permasalahan Sumber Daya Air (SDA), maka perbaikan pengelolaan SDA tidak bisa hanya ditujukan kepada sistem pengelolaan semata. Perbaikan ini akan berhasil apabila dilakukan pula usaha perbaikan terhadap kelembagaan serta hubungan antar lembaga yang berkepentingan dengan pengelolaan SDA (Usman et.al, 2001). Terkait hal tersebut maka diperlukan adanya kelembagaan pertanian untuk mengelola sistem irigasi secara efektif. Kelembagaan petani yang terdapat dalam sistem pengairan ialah Perkumpulan Petani Pemakai Air (P3A), yang mempunyai tanggung jawab mengelola jaringan irigasi tersier (Waridin, 2009; Suriana, 2019).

P3A mempunyai peran penting dalam pembangunan pertanian sebagai lembaga yang mempunyai kewenangan dalam pengelolaan irigasi. Berdasarkan Undang-Undang Nomor 7 Tahun 2004 tentang Sumber Daya Air dan Peraturan Pemerintah Nomor20 Tahun 2006 tentang irigasi, maka kebijakan pengelolaan irigasi akan dilakukan melalui pendekatan pengelolaan irigasi partisipatif. Dengan kebijakan tersebut, pengembangan (pembangunan/rehabilitasi) terhadap irigasi tidak hanya menjadi wewenang dan tanggung jawab dari pemerintah pusat maupun pemerintah daerah, tetapi juga merupakan tanggung jawab petani. Oleh karena itu diperlukan adanya partisipasi dari petani atau anggota kelompok untuk mewujudkan dinamika kelompok yang baik (Yulianti, 2013; Yusuf, 2018)). Partisipasi 
tidak hanya menjadi pendorong dinamika kelompok, tetapi lebih dari itu ia adalah instrumen penyesuaian kelembagaan dalam merespons perubahan sosio-teknis (Yunus et.al, 2016; Salman, 1995).

Jaringan irigasi Taccipi Desa Malimpung, Kecamatan Patampanua, Kabupaten Pinrang telah memiliki kelembagaan. Secara administratif jaringan irigasi ini termasuk dalam wilayah kerja daerah irigasi Saddang Utara tetapi tidak bergabung dengan bendungan Benteng. Irigasi ini memiliki waduk tersendiri yakni Waduk Taccipi dengan luas areal potensial $687 \mathrm{Ha}$ dan luas areal fungsional seluas $552 \mathrm{Ha}$. Agar manfaat irigasi maksimal, partisipasi anggota kelompok P3A dalam program Pengembangan Jaringan Irigasi (PJI), sangat penting. Ini disebabkan karena anggota dapat berperan bukan hanya sebagai objek tetapi juga sebagai subjek pembangunan. Kesediaan masyarakat untuk mengambil bagian dalam penyelenggaraan program pembangunan juga merupakan indikasi adanya kemampuan awal masyarakat untuk keberdayaan (Mikkelsen, 2003; Salman, 2002; ) Penelitian ini bertujuan menganalisis partisipasi masyarakat petani melalui P3A dalam program PJI.

\section{Metode Penelitian}

Penelitian ini dilaksanakan di Daerah Irigasi Taccipi, Desa Malimpung, Kecamatan Patampanua, Kabupaten Pinrang, Sulawesi Selatan. Lokasi ini dipilih karena merupakan salah satu kecamatan yang menerima bantuan program PJI terbanyak di Kabupaten Pinrang. Sampel penelitian sebanyak 71 orang atau 20\% dari populasi (355 orang). Metode penelitian survei dengan pendekatan kuantitatif. Teknik pengumpulan data adalah wawancara dengan kuisioner.

Bentuk pasrtisipasi petani anggota P3A dianalisis secara deskpritif, sedangkan untuk mengukur tingkat partisipasi petani anggota P3A Jembatan Bessi, P3A Kaluppang, dan P3A Lamacinna digunakan sistem skoring, yaitu memberi skor pada item pertanyaan yang menyatakan partisipasi petani pada kegiatan PJI. Pemberian skor menggunakan skala Likert. Menurut Arikunto (2010), skala Likert merupakan skala yang berisi lima tingkatan jawaban mengenai kesetujuan responden terhadap pernyataan yang dikemukakan mendahului opsi jawaban yang disediakan, yaitu:

- Skor 5 : Untuk kategori sangat aktif (sangat tinggi)

- Skor 4 : Untuk kategori aktif (tinggi)

- Skor 3 : Untuk kategori cukup aktif (sedang)

- Skor 2 : Untuk kategori kurang aktif (rendah)

- Skor 1 : Untuk kategori tidak aktif (sangat rendah)

Adapun rumus yang digunakan untuk menghitung nilai rata-rata terbobot adalah sebagai berikut:

Dimana : $\bar{x}=$ Rata-rata terbobot

$$
\bar{x}=\frac{\sum f i . w i}{N}
$$

$$
\begin{aligned}
& f i=\text { Frekuensi } \\
& w i=\text { Bobot } \\
& N=\text { Jumlah Keseluruhan }
\end{aligned}
$$

Setelah rata-rata terbobot diperoleh hasilnya, rentang skala penelitian ditentukan untuk menentukan posisi tanggapan sampel. Rentang skala dihitung dengan menggunakan rumus sebagai berikut: 
dimana : $R s=$ Rentang skala

$$
R s=\frac{R(\text { Bobot })}{M}
$$

$R=$ Bobot terbesar - bobot terkecil

$M=$ Banyaknya kategori pembobotan

Kategori tingkat partisipasi dapat dilihat pada Tabel-1.

Tabel-1

Rentang Skala Tingkat Partisipasi Petani Anggota P3A

\begin{tabular}{|l|l|}
\hline \multicolumn{1}{|c|}{ Kategori } & Rentang Skala \\
\hline Tidak Aktif (Sangat Rendah) & $1,00>$ Rata-rata terbobot $\leq 1,80$ \\
\hline Kurang Aktif (Rendah) & $1,81>$ Rata-rata terbobot $\leq 2,60$ \\
\hline Cukup Aktif (Sedang) & $2,61>$ Rata-rata terbobot $\leq 3,40$ \\
\hline Aktif ( Tinggi) & $3,41>$ Rata-rata terbobot $\leq 4,20$ \\
\hline Sangat aktif (Sangat Tinggi) & $4,21>$ Rata-rata terbobot $\leq 5,00$ \\
\hline
\end{tabular}

\section{Hasil dan Pembahasan}

\section{(1) Kegiatan PJI di Daerah Irigasi Taccipi}

Bantuan pemerintah dalam bentuk program PJI diberikan kepada P3A Jembatan Bessi, P3A Kaluppang dan P3A Lamacinna pada awal 2015. Penentuan kelompok tersebut didasarkan pada kebutuhan, tingkat keaktifan, dan kemajuan kelompok. Pengajuan nama kelompok dilakukan oleh penyuluh Desa Malimpung kepada Dinas Pertanian dan Hortikultura Kabupaten Pinrang.

PJI mencakup bantuan berupa uang yang ditransfer langsung ke rekening P3A, benih padi ciherang, pupuk urea, dan pupuk NPK. Bantuan benih dan pupuk dibagikan kepada anggota P3A yang besarnya sesuai luas lahan masing-masing anggota P3A. Pagu penerima program PJI pada tahun 2015 masing-masing sebesar Rp. 66.000.000,00 (BPP Kecamatan Patampanua, 2015).

Terdapat beberapa tahapan kegiatan dalam PJI yang dijalankan pengurus bersama anggota dalam P3A. Pertama, survei lokasi dan pengukuran. Ini dilakukan untuk menentukan lokasi dan panjang saluran irigasi tersier yang akan dibangun pada masing-masing blok bagi. Pelaksanaan survei lokasi dan pengukuran dikoordinasikan dengan instansi terkait. Tahapan ini dilakukan pada bulan Januari 2015 dengan tiga kali pertemuan (tiga hari). Pada P3A Jembatan Bessi dilakukan satu kali pertemuan di saluran irigasi tersier bagian hulu, P3A Kaluppang satu kali pertemuan (satu hari) di saluran irigasi tersier bagian tengah, dan P3A Lamacinna dengan satu kali pertemuan (satu hari) di saluran irigasi tersier bagian hilir. Pelaksanaan kegiatan dibiayai oleh daerah dan dilaksanakan oleh pendamping atau penyuluh UPT Dinas Pertanian dan Hortikultura di Kecamatan Patampanua bersama pengurus masing-masing P3A, ketua masing-masing blok, serta dibantu beberapa anggota masing-masing P3A. 
Kedua, musyawarah anggota. Ini membahas proses pelaksanaan PJI yang akan dikelola anggota masing-masing P3A. Musyawarah anggota dilakukan pada bulan Januari 2015 dengan tiga kali pertemuan di Kantor Desa Malimpung. Musyawarah dilaksanakan oleh Pendamping atau bimbingan Tim Teknis atau koordinator lapangan dengan pengurus dan beberapa anggota P3A Jembatan Bessi, P3A Kaluppang dan P3A. Musyawarah membicarakan komponen yang akan dimasukkan dalam isi proposal, seperti kebutuhan bahan, jumlah tenaga kerja, biaya, sumber biaya dan waktu pelaksanaan, termasuk lokasi dan panjang irigasi yang diajukan juga dibahas dalam musyawarah tersebut.

Ketiga, pembuatan proposal. Ini dilakukan pada Januari 2015. Proposal dibuat oleh pengurus P3A Jembatan Bessi, P3A Kaluppang dan P3A Lamacinna dengan arahan penyuluh (pendamping). Proposal berisi Surat Permohonan Bantuan kepada Dinas Pertanian dan Hortikultura Kabupaten Pinrang, latar belakang, dasar, tujuan, waktu kegiatan, dan sasaran, visi misi dan rencana strategis, penutup dan lampiran. Setelah selesai, proposal diberikan langsung kepada Ibu Rahma S.PKP., KUPT Dinas Pertanian di Kecamatan Patampanua untuk diserahkan ke Dinas Pertanian dan Hortikultura Kabupaten Pinrang.

Keempat, pelaksanaan konstruksi PJI. Ini dilaksanakan secara swakelola oleh anggota P3A Jembatan Bessi, P3A Kaluppang dan P3A Lamacinna secara bergotongroyong dengan memanfaatkan tenaga anggota. Kepada anggota kelompok yang berpartisipasi dalam kegiatan pengembangan jaringan irigasi, jika diperlukan dapat diberikan intensif kerja yang nilainya ditentukan berdasarkan musyawarah kelompok dan harus tertulis dalam RUKK. Berikut ini tahapan konstruksi yang dilakukan anggota P3A Jembatan Bessi, P3A Kaluppang dan P3A Lamacinna.

Pembersihan lokasi. Ini dilakukan dalam tiga kali pertemuan pada saat turun sawah, satu hari pada lokasi P3A Jembatan Bessi, satu hari pada lokasi P3A Kaluppang dan satu hari pada lokasi P3A Lamacinna. Sebelum pembangunan irigasi, anggota P3A bergotong-royong membersihkan lokasi jaringan irigasi seperti memotong rumput liar dan semak-semak, membersihkan saluran dari sampah dan kotoran, memindahkan kayu, bebatuan dan lainnya yang dapat mengganggu proses pembersihan saluran.

Pengadaan bahan material. Ini dilakukan pada Maret 2015 di musim tanam kedua oleh masing-masing pengurus P3A dan beberapa anggota lainnya yang terdaftar sebagai pekerja. Adapun bahan material seperti batu, kerikil, pasir, semen, besi serta bahan lainnya yang akan digunakan saat proses pembangunan baru saluran irigasi tersier.

Penyiapan alat dan tenaga kerja. Ini juga dilakukan pada Maret 2015 musim tanam kedua. Peralatan yang diperlukan untuk proses pembangunan baru jaringan irigasi tersier sebagian besar merupakan milik anggota yang sengaja dipinjam. Tenaga kerja berasal dari anggota kelompok P3A Jembatan Bessi lima orang, P3A Kaluppang enam orang, dan P3A Lamacinna lima orang. Tidak seluruh anggota berpartisipasi dalam proses pengerjaan karena jumlah tenaga kerja sudah ditentukan dan diberikan upah kerja berdasarkan musyawarah P3A dengan bimbingan tim teknis atau koordinator lapangan pada Januari 2015 di Kantor Desa Malimpung yang tertulis dalam RUKK.

Pengerjaan konstruksi. Seluruh blok bagi P3A Jembatan Bessi, P3A Kaluppang dan P3A Lamacinna memulai pengerjaan bangunan irigasi pada April 2015 dalam 
satu musim tanam yaitu setelah panen. Lamanya pengerjaan masing-masing blok bagi berbeda-beda, sesuai dengan jumlah tenaga kerja yang digunakan dan panjang saluran irigasi tersier yang dibangun. Seminggu setelah pembangunan saluran irigasi tersier selesai, ketua masing-masing P3A bertanggung jawab untuk menyelesaikan Laporan Pertanggung Jawaban (LPJ) yang diserahkan ke Dinas Pertanian dan Hortikultura Kabupaten Pinrang melalui KUPT Dinas Pertanian Kecamatan Patampanua yang berisi Surat Pernyataan Penyelesaian Pekerjaan (SP3), Rencana Anggaran Biaya (RAB), rekapitulasi kebutuhan alat dan bahan, harga satuan upah, bahan dan sewa peralatan, analisis harga satuan tahun anggaran 2015, kebutuhan tenaga kerja dan bahan, rencana detail saluran, denah lokasi, dan lampiran yang berisi nota pembelian serta foto-foto mulai pengerjaan awal hingga selesai.

\section{(2) Partisipasi Petani Anggota P3A Pada Kegiatan PJI}

\section{A. Partisipasi dalam Penyusunan Rencana Usulan Kegiatan Kelompok}

Penyusunan Rencana Usulan Kegiatan Kelompok (RUKK) dilaksanakan secara musyawarah yang dengan fasilitator Pendamping atau tim Teknis atau koordinator lapangan yang diikuti seluruh pengurus dan beberapa anggota P3A. Kegiatan ini dilaksanakan pada Januari 2015 di musim tanam pertama dengan tiga kali pertemuan di Kantor Desa Malimpung. Musyawarah RUKK meliputi kegiatan menyusun rencana volume (panjang) saluran dan komponen jaringan irigasi tersier yang akan dibangun atau direhabilitasi, menyusun rencana kebutuhan bahan dan menyusun rencana jumlah tenaga kerja, menyusun rencana biaya, menyusun rencana sumber biaya, dan menyusun rencana waktu pelaksanaan pembangunan baru atau rehabilitasi jaringan irigasi tersier.

Tabel-2

Tingkat Partisipasi Petani Anggota P3A Pada Kegiatan Penyusunan RUKK

\begin{tabular}{|c|c|c|c|c|c|c|c|}
\hline \multirow{3}{*}{ No. } & \multirow{3}{*}{$\begin{array}{c}\text { Kegiatan Penyusunan } \\
\text { RUKK }\end{array}$} & \multicolumn{6}{|c|}{ Kelompok P3A } \\
\hline & & \multicolumn{2}{|c|}{ Jembatan Bessi } & \multicolumn{2}{|c|}{ Kaluppang } & \multicolumn{2}{|c|}{ Lamacinna } \\
\hline & & $\overline{\boldsymbol{x}}$ & $\%$ & $\bar{x}$ & $\%$ & $\bar{x}$ & $\%$ \\
\hline 1. & $\begin{array}{l}\text { Menyusun rencana volume } \\
\text { (panjang) saluran dan } \\
\text { komponen jaringan irigasi }\end{array}$ & 2,08 & 18,29 & 2,57 & 19,91 & 2,50 & 19,68 \\
\hline 2. & $\begin{array}{l}\text { Menyusun rencana } \\
\text { kebutuhan bahan }\end{array}$ & 1,83 & 16,10 & 2,05 & 15,88 & 2,08 & 16,38 \\
\hline 3. & $\begin{array}{l}\text { Menyusun rencana jumlah } \\
\text { tenaga kerja }\end{array}$ & 1,83 & 16,10 & 2,05 & 15,88 & 2,00 & 15,75 \\
\hline 4. & Menyusun rencana biaya & 1,88 & 16,53 & 2,14 & 16,57 & 2,08 & 16,38 \\
\hline 5 & $\begin{array}{l}\text { Menyusun rencana sumber } \\
\text { biaya }\end{array}$ & 1,83 & 16,10 & 2,05 & 15,88 & 2,04 & 16,06 \\
\hline 6 & $\begin{array}{l}\text { Menyusun rencana waktu } \\
\text { pelaksanaan kegiatan }\end{array}$ & 1,92 & 16,88 & 2,05 & 15,88 & 2,00 & 15,75 \\
\hline & Jumlah & 11,37 & 100 & 12,91 & 100 & 12,70 & 100 \\
\hline & $\begin{array}{l}\text { Total Rata-rata terbobot } \\
\text { Partisipasi }\left(\bar{x}_{\mathrm{p}}\right)\end{array}$ & 1,90 & & 2,15 & & 2,12 & \\
\hline & Kategori Rentang Skala & Rendah & & Rendah & & Rendah & \\
\hline
\end{tabular}


Berdasarkan Tabel-2, rata-rata terbobot untuk indikator kegiatan penyusunan RUKK pada P3A Jembatan Bessi adalah 1,90, P3A Kaluppang adalah 2,15, dan P3A Lamacinna adalah 2,12. Nilai ini berada dalam rentang skala 1,81 $>\bar{x} \leq 2,60$ sehingga dapat disimpulkan bahwa partisipasi petani anggota P3A Jembatan Bessi, P3A Kaluppang dan P3A Lamacinna pada kegiatan penyusunan RUKK berada pada kategori rendah. Rendahnya partisipasi anggota kelompok P3A disebabkan koordinasi yang kurang maksimal oleh masing-masing ketua dan pengurus lainnya kepada anggota. Selain itu, kurangnya kesadaran dan kemauan yang dimiliki oleh anggota kelompok P3A, dimana beranggapan bahwa sudah ada yang mewakili kelompok untuk menghadiri musyawarah tersebut, seperti ketua, sekretaris, bendahara dan anggota lainnya. Sebagian besar petani anggota kelompok P3A yang ikut berpartisipasi dengan sesekali hadir, hanya karena turut meramaikan sehingga mengikuti jalannya rapat tetapi tidak aktif memberikan ide atau pendapat dengan alasan sudah ada perwakilan dari pengurus.

Hasil penelitian ini sejalan dengan hasil penelitian yang dilakukan oleh Waridin (2009) yang menyatakan bahwa partisipasi dalam dimensi-dimensi perencanaan pada umumnya masih rendah. Masyarakat hanya digunakan sebagai alat publikasi saja, meskipun masyarakat yang terlibat dalam kegiatan, namun pada kenyataannya masyarakat tidak pernah aktif memberikan masukan atau usulanusulan dalam proses kegiatan perencanaan.

\section{B. Partisipasi pada Kegiatan Konstruksi Saluran Irigasi Tersier}

Pembangunan baru saluran irigasi tersier merupakan kegiatan konstruksi PJI yang dilaksanakan pada April 2015 dalam satu musim tanam yaitu setelah panen. Kegiatan ini dilaksanakan secara swakelola oleh P3A dengan bergotong-royong memanfaatkan tenaga kerja anggota. Kegiatan pembangunan baru saluran irigasi tersier meliputi kegiatan penggalian, penimbunan, pembuatan pondasi, dan pemasangan batu kali dan plester. Tingkat partisipasi petani anggota masing-masing kelompok P3A pada kegiatan pembangunan baru saluran tersier dapat dilihat pada Tabel-3.

Tabel-3

Tingkat Partisipasi Petani Anggota P3A Pada Kegiatan Konstruksi Saluran Irigasi

\begin{tabular}{|c|c|c|c|c|c|c|c|}
\hline \multirow{3}{*}{ No. } & \multirow{3}{*}{$\begin{array}{c}\text { Kegiatan Pembangunan } \\
\text { baru Saluran Irigasi } \\
\text { Tersier }\end{array}$} & \multicolumn{6}{|c|}{ Kelompok P3A } \\
\hline & & \multicolumn{2}{|c|}{ Jembatan Bessi } & \multicolumn{2}{|c|}{ Kaluppang } & \multicolumn{2}{|c|}{ Lamacinna } \\
\hline & & $\bar{x}$ & $\%$ & $\bar{x}$ & $\%$ & $\bar{x}$ & $\%$ \\
\hline 1. & Penggalian & 2,00 & 24,63 & 2,05 & 24,46 & 1,92 & 23,36 \\
\hline 2. & Penimbunan & 1,92 & 23,65 & 2,19 & 26,13 & 1,96 & 23,84 \\
\hline 3. & Pembuatan Pondasi & 1,87 & 23,03 & 2,14 & 25,54 & 1,88 & 22,87 \\
\hline 4. & $\begin{array}{l}\text { Pemasangan Batu Kali } \\
\text { dan Plester }\end{array}$ & 2,33 & 28,69 & 2,00 & 23,87 & 2,46 & 29,93 \\
\hline & Jumlah & 8,12 & 100 & 8,38 & 100 & 8,22 & 100 \\
\hline & $\begin{array}{l}\text { Total Rata-rata terbobot } \\
\text { Partisipasi }(\bar{x} p)\end{array}$ & 2,03 & & 2,10 & & 2,05 & \\
\hline & Kategori Rentang Skala & Rendah & & Rendah & & Rendah & \\
\hline
\end{tabular}


Berdasarkan Tabel-3, rata-rata terbobot untuk indikator kegiatan konstruksi pada pembangunan baru saluran irigasi tersier pada P3A Jembatan Bessi adalah 2,03, P3A Kaluppang adalah 2,10, dan P3A Lamacinna adalah 2,05. Nilai ini berada dalam rentang skala $1,81>\bar{x} \leq 2,60$ sehingga dapat disimpulkan bahwa partisipasi petani anggota P3A Jembatan Bessi, P3A Kaluppang dan P3A Lamacinna pada kegiatan pembangunan baru saluran tersier di daerah irigasi Taccipi berada pada kategori rendah.

Keterlibatan anggota P3A dalam kegiatan konstruksi saluran irigasi tersier menunjukkan bahwa anggota P3A yang berada di daerah hulu, tengah dan hilir relatif sama memiliki partisipasi yang tergolong rendah. Rendahnya partisipasi petani anggota P3A disebabkan tidak semua anggota ikut berpartisipasi dalam proses pengerjaan, karena tenaga kerja sudah ditentukan jumlahnya dan diberikan upah kerja. Masing-masing pengurus kelompok P3A bertanggung jawab mencari anggota P3A yang ingin menjadi kepala tukang. Kemudian penentuan jumlah tenaga kerja ditentukan oleh kepala tukang (pekerja) berdasarkan dana/anggaran upah tenaga kerja yang telah disediakan atau ditentukan berdasarkan musyawarah kelompok P3A dengan bimbingan Tim Teknis atau Koordinator Lapangan sesuai RUKK.

Pada P3A Jembatan Bessi yang berada pada daerah hulu memiliki jumlah tenaga kerja yang digunakan pada kegiatan konstruksi saluran tersier berjumlah lima orang pekerja. Adapun volume (panjang) saluran tersier yang di bangun yaitu $125 \mathrm{~m}$. Pada P3A Kaluppang yang berada pada daerah tengah memiliki jumlah tenaga kerja dalam kegiatan konstruksi saluran tersier berjumlah enam orang pekerja. Adapun volume (panjang) saluran tersier yang di bangun yaitu $125 \mathrm{~m}$. Pada kelompok P3A Jembatan Bessi yang berada pada daerah hilir memiliki jumlah tenaga kerja yang digunakan pada kegiatan konstruksi saluran tersier berjumlah 5 orang pekerja. Adapun volume (panjang) saluran tersier yang di bangun yaitu 125 m.

\section{Bentuk Partisipasi Petani Anggota P3A dalam PJI}

Bentuk partisipasi petani anggota kelompok P3A Jembatan Bessi, P3A Kaluppang, dan P3A Lamacinna pada kegiatan PJI di daerah irigasi Taccipi adalah sebagai berikut.

Partisipasi dalam bentuk pemikiran. Partisipasi petani anggota P3A dalam bentuk pemikiran berupa ide, saran serta pendapat yang diberikan pada saat musyawarah. Musyawarah anggota bertujuan untuk membahas proses pelaksanaan PJI dimana masing-masing anggota dapat mengemukakan pendapatnya dalam musyawarah tersebut. Komponen yang akan dimasukkan dalam isi proposal, termasuk lokasi dan panjang irigasi yang diajukan juga dibahas dalam musyawarah.

Partisipasi dalam bentuk tenaga kerja. Partisipasi petani anggota P3A dalam bentuk tenaga kerja berupa ikut membantu membersihkan lokasi saluran irigasi tersier yang akan dibangun, menggali saluran, mencampur bahan atau adonan semen untuk pembangunan, dan membuat pondasi yang dilakukan secara bergotong-royong atau swadaya. Tenaga kerja berasal dari anggota P3A Jembatan Bessi, Kaluppang, dan Lamacinna. 
Partisipasi dalam bentuk penyediaan bahan bangunan. Bahan bangunan yang digunakan untuk kegiatan konstruksi saluran irigasi tersier disediakan oleh pengurus masing-masing kelompok P3A sehingga pekerja/tenaga kerja hanya bertugas mengerjakan pembangunannya. Partisipasi petani anggota P3A dalam bentuk bahan bangunan untuk kegiatan konstruksi saluran irigasi tersier hanya dalam bentuk jasa penyedia (jaminan) pengambilan bahan bangunan berupa semen, batu dan pasir.

Partisipasi dalam bentuk penyediaan dana. Dana untuk kegiatan PJI ini tersedia dalam mata anggaran belanja bantuan sosial untuk pemberdayaan sosial dalam bentuk uang. Dana atau biaya tersebut dipergunakan untuk kegiatan fisik pengembangan jaringan irigasi dengan mengacu pada Pedoman Umum Bansos Direktorat Jenderal Sarana dan Prasarana Pertanian. Segala pekerjaan yang dilakukan oleh kelompok P3A Jembatan Bessi, P3A Kaluppang, dan P3A Lamacinna, diluar bantuan program Pengembangan Jaringan Irigasi (PJI) baik untuk keperluan pemberdayagunaan air, pemeliharaan, dan perbaikan jaringan irigasi atau kegiatan lainnya dibiayai sendiri oleh masing-masing P3A. Sumber pembiayaannya berasal dari iuran IPAIR anggota, sumbangan atau bantuan, dan usaha-usaha lain yang sah menurut hukum.

IPAIR P3A selalu dibayar oleh masing-masing anggota. Beberapa anggota mengaku tidak sekaligus membayar dan ada beberapa anggota yang tidak membayar sesuai waktu yang ditetapkan (seusai panen) karena ada kebutuhan yang harus didahulukan. Bendahara kelompok P3A Jembatan Bessi, P3A Kaluppang, dan P3A Lamacinna mengaku selama ini tidak terjadi masalah serius tentang iuran, meski anggota ada yang terlambat membayar. Iuran anggota biasanya dikumpulkan terlebih dahulu kepada ili-ili masing-masing blok, selanjutnya iuran diserahkan ke P3A untuk dibagi sesuai dengan persentase pengalokasian iuran kelompok P3A Jembatan Bessi, P3A Kaluppang dan P3A Lamacinna.

Partisipasi dalam bentuk pemeliharaan. Pemeliharaan pada kegiatan konstruksi PJI dilaksanakan oleh pekerja/tenaga kerja masing-masing kelompok P3A itu sendiri. Adapun kegiatan pemeliharaan yang dilakukan mencakup pemeliharaan berkala, perawatan dan perbaikan yang dilaksanakan secara secara terencana oleh GP3A bersama dengan Dinas yang membidangi irigasi dalam hal ini UPTD Pengairan Teppo serta Ulu-Ulu yang setiap tahunnya bekerja sama dengan para petani anggota P3A. Pemeliharaan berkala saluran irigasi di daerah irigasi Taccipi dilakukan empat kali dalam satu musim tanam tergantung kondisi irigasi. Kegiatan dalam pemeliharaan berkala antara lain pemotongan rumput, pengerukan lumpur atau waled, pembersihan sampah di saluran, penutupan bocoran, pengecatan pintu, pelumasan pintu, dan pengamanan jaringan irigasi serta kegiatan pemeliharaan berkala lainnya.

\section{Kesimpulan}

Pelaksanaan kegiatan PJI di daerah irigasi Taccipi secara umum telah sesuai dengan prosedur pelaksanaan yang belaku. Diawali dengan tahapan persiapan oleh pengurus dan anggota didampingi oleh penyuluh meliputi musyawarah anggota, survei lokasi dan pengukuran, serta pembuatan proposal dalam hal ini ditujukan kepada Dinas Pertanian dan Hortikultura Kabupaten Pinrang. Pelaksanaan 
konstruksi dilakukan secara swakelola oleh masing-masing kelompok P3A dengan memanfaatkan tenaga kerja anggota meliputi pembersihan lokasi, pembelian bahan material, persiapan alat dan tenaga kerja serta pelaksanaan konstruksi itu sendiri.

Tingkat partisipasi petani anggota P3A pada kegiatan penyusunan rencana usulan kelompok berada pada kategori rendah dengan total rata-rata terbobot P3A Jembatan Bessi (Hulu) adalah 1,90, P3A Kaluppang (Tengah) adalah 2,15 dan P3A Lamacinna (Hilir) adalah 2,12. Pada kegiatan konstruksi saluran tersier berada pada kategori rendah dengan total rata-rata terbobot P3A Jembatan Bessi (Hulu) adalah 2,03, P3A Kaluppang (Tengah) adalah 2,10 dan P3A Lamacinna (Hilir) adalah 2,05.

Bentuk partisipasi petani anggota P3A pada kegiatan PJI di daerah irigasi Taccipi mulai dari bentuk pemikiran berupa ide, saran serta pendapat pada saat musyawarah namun tidak semua anggota masing-masing P3A mengikuti musyawarah tersebut. Partisipasi dalam bentuk tenaga kerja berupa ikut membantu membersihkan lokasi jaringan irigasi, mencampur bahan atau adonan semen, dan membantu membuat pondasi saluran irigasi tersier namun tidak semua anggota masing-masing P3A ikut berpartisipasi dalam kegiatan, petani yang tidak terdaftar dalam RUKK ikut menyumbangkan partisipasinya secara sukarela. Partisipasi dalam bentuk bahan bangunan hanya berupa jasa penyedia pengambilan bahan bangunan. Partisipasi dalam bentuk dana untuk kegiatan program PJI ini telah tersedia dalam mata anggaran belanja bantuan sosial untuk pemberdayaan sosial. Partisipasi dalam bentuk pemeliharaan hanya dilakukan oleh pekerja masing-masing kelompok P3A selama proses pembangunan masih berlangsung.

\section{Daftar Pustaka}

Arikunto, S. 2010. Prosedur Penelitian. PT Rineka Cipta. Jakarta.

Lastinawati, E. 2011. Partisipasi Petani dalam Pelaksanaan Program Pengembangan Usaha Agribisnis Pedesaan (PUAP) di Kabupaten OKU. Jurnal Agribisnis Vol. 3. No. 5, Maret 2011.

Lugiarti, E. 2004. Peningkatan Partisipasi Masyarakat dalam Proses Perencanaan Program Pengembangan Masyarakat di Komunitas Desa Cijayanti. Tesis. Bogor: Sekolah Pascasarjana, IPB.

Mardikanto, T., 2016. Partisipasi Petani Peserta Terhadap Program Sistem Pertanian Terpadu (SPT) (Studi Kasus Desa Tambak Kecamatan Langgam, Kabupaten Pelalawan Provinsi Riau). Tesis. Bogor: Sekolah Pascasarjana, IPB.

Mikkelsen, B. 2003. Metode Penelitian Partisipatoris dan Upaya-Upaya Pemberdayaan. Yayasan Obor Indonesia. Jakarta.

Salman, D., 1995. "Arah Perubahan Sosial di Pedesaan Pasca Revolusi Hijau". Analisis, XXIV, No.1.

Salman, D., 2002. Apa dan Bagaimana Pemberdayaan Masyarakat (Makalah Seminar). Makassar: PSKMP Unhas. 
Suriana, 2019. Pengetahuan, Sikap, Dan Partisipasi Petani Anggota P3A Dalam Operasi Dan Pemeliharaan Daerah Irigasi Pattiro Kecamatan Barebbo, Kabupaten Bone. Skripsi. Makassar: Fakultas Pertanian, Universitas Hasanuddin.

Waridin, 2009. Faktor Yang Mempengaruhi Partisipasi Nelayan Dalam Pembangunan Komunitas di TPI Asemdoyong, Kabupaten Pemalang, Jawa Tengah. Jurnal Ekonomi Pembangunan Balai Penelitian Pengembangan Ekonomi, Volume 8, Nomor 1. Surakarta: Fakultas Ekonomi Universitas Muhamadiyah Surakarta.

Wihandoko, A. 2015. Persepsi Dan Tingkat Partisipasi Masyarakat Pada Program Nasional Pemberdayaan Masyarakat Mandiri (PNPM Mandiri) di Kabupaten Mesuji (Studi Kasus Kecamatan Tanjungraya). Jurnal Ekonomi Pembangunan, Volume 4, Nomor 2. Lampung: Magister Ilmu Ekonomi FEB Unila.

Yulianti, 2013. Tingkat Partisipasi Dalam Operasi Dan Pemeliharaan Untuk Perkumpulan Petani Pemakai Air (P3A) Di Daerah Irigasi Boro. Skripsi. Semarang: Fakultas Pertanian, Universitas Diponegoro.

Yunus, A., D. Salman, EB. Demmallino, NM. Viantika, 2016. “Sosiotechnical Change and Institutional Adjustment in Paddy Rice Farming During Post Green Revolution in Indonesia". International Journal of Agriculture Science, 4 (2): 218227.

Yusuf, R.P. 2018. Pengaruh Faktor-Faktor Partisipasi Terhadap Tingkat Partisipasi Petani Anggota P3A Dalam Kegiatan Pengelolaan Saluran Irigasi Bantimurung (Studi Kasus Di Desa Alatengae, Kecamatan Bantimurung, Kabupaten Maros, Sulawesi Selatan). Skripsi. Makasaar: Fakultas Pertanian, Universitas Hasanuddin. 